http://dx.doi.org/10.4314/njt.v37i4.18

\title{
DEVELOPMENT AND CHARACTERIZATION OF A CATALYTIC MEMBRANE FOR VOLATILE ORGANIC COMPOUND COMBUSTION
}

\author{
M. N. Kajama ${ }^{1,}{ }^{*}$ and Y. Yildirim ${ }^{2}$

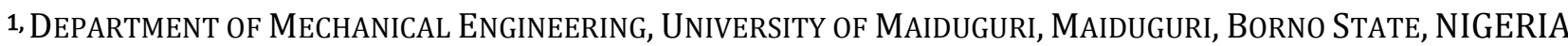 \\ 2, DEPARTMENT OF ENVIRONMENTAL ENGINEERING, BULENT ECEVIT UNIVERSITY, ZONGULDAK, TURKEY \\ E-mail addresses: ${ }^{1}$ mohd_nasiru@yahoo.com; ${ }^{2}$ yilmaz.yildirim@beun.edu.tr
}

\begin{abstract}
Platinum-alumina $\left(\mathrm{Pt} / \gamma-\mathrm{Al}_{2} \mathrm{O}_{3}\right)$ catalytic membranes were obtained using the reservoir technique for the combustion of volatile organic compounds (VOCs). The membranes were characterized by scanning electron microscopy and energy dispersive X-ray analysis (SEM-EDXA) observation, Brunauer-Emmett-Teller (BET) measurement and gas permeation. Propane $\left(C_{3} H_{8}\right)$ and n-butane $\left(C_{4} H_{10}\right)$ combustion was obtained. Maximum VOC conversion for propane and n-butane of 93 and $48(\%)$ was achieved on $3.52 w t \%$ Pt catalyst at a temperature of 427 and $259\left({ }^{\circ} \mathrm{C}\right)$ and flow rates of between 185-222 and 295-379 ( $\mathrm{ml} / \mathrm{min})$ without any changes in conversion. The combustion results of $C_{3} \mathrm{H}_{8}$ and $\mathrm{C}_{4} \mathrm{H}_{10}$ corroborate with literature on $\mathrm{Pt} / \gamma-\mathrm{Al}_{2} \mathrm{O}_{3}$ catalysts. The conversion was achieved using flow-through catalytic membrane reactor operating in the Knudsen flow regime.
\end{abstract}

\section{INTRODUCTION}

VOCs are released into the atmosphere from chemical plants, aircraft manufacturers, food processing facilities, textile manufacturers, painting facilities, wood stoves, etc. All organic compounds that boil at 50$260\left({ }^{\circ} \mathrm{C}\right)$, exclusive of pesticides but including dichloromethane, are VOCs [1]. VOCs are grouped as aliphatic hydrocarbons such as propane and n-butane, aromatic hydrocarbons include toluene and benzene, ketones for example acetone, among others [2]. Ground-level ozone build-up is largely due to the increased availability of ozone forming precursor VOCs and oxides of nitrogen $\left(\mathrm{NO}_{\mathrm{x}}\right)$. Furthermore, in the presence of VOCs and nitric oxide (NO), the degradation reactions of VOCs could lead to the formation of intermediate radicals such as peroxy radicals $\left(\mathrm{RO}_{2}\right)$. Peroxy radicals react with atmospheric NO, converting NO to nitrogen dioxide $\left(\mathrm{NO}_{2}\right)$ which then photolyzes to form tropospheric ozone [3]. Additionally, some symptoms related to adverse health impact are quite common and are associated with short term exposure to VOCs. These symptoms include; headaches, allergic skin reaction, visual disorders, dizziness, coughing, eye and respiratory tract irritation and fatigue. Likewise, brain damage, damage to the nervous, kidney, reproductive and immune systems are associated with long term exposure to VOCs [4]. Emissions of VOCs could be a result of natural sources, although, most VOC emissions result from anthropogenic sources. The degree of VOCs released yearly into the atmosphere from man-made sources alone constitute to about 235 million tonnes [4]. From an environmental point of view, curtailing these vapour emissions could lead to a vital landmark in the oil and process industries.

Consequently, imposing stricter regulations can actually abate the release of VOCs into the environment [5]. In recent years, the emissions of VOCs have been rigorously regulated across the globe. For example, "in the air quality standards developed by the United States Environmental Protection Agency (USEPA) the maximum 3-hour concentration of 0.24 parts per million (ppm) hydrocarbon content should not be exceeded for a period of more than a year" $[6,7]$. The Gothenburg protocol also states that by 2020 the European Union (EU) countries agree to curb VOC emission levels by nearly $50 \%$ compared to the year 2000 [5].

There are different techniques/methods applied to control VOC emissions. These techniques are categorised as either destruction or recovery (Figure 1). Pollutants can be destroyed by either incineration/oxidation or by biodegradation. The most extensively applied VOC destruction techniques/methods are thermal and catalytic oxidation. These are applied whereby VOCs are mixed 
with oxygen $\left(\mathrm{O}_{2}\right)$ at specified temperatures and the products are carbon dioxide $\left(\mathrm{CO}_{2}\right)$ and water $\left(\mathrm{H}_{2} \mathrm{O}\right)$. In general, the chemical reaction is written as:

$$
\text { VOCs }+\mathrm{O}_{2}=\mathrm{CO}_{2}+\mathrm{H}_{2} \mathrm{O}
$$

Membrane reactors have being receiving considerable attention for over half a century and a number of papers have been published on the subject of membrane science, catalysis and chemical engineering [8-12]. Membranes are used as an active material in chemical conversion in accelerating the reaction rate, selectivity and yield. Membrane reactors have been largely demonstrated on the laboratory scale for hydrogenation, oxidation reactions, dehydrogenation, and decomposition [8].

The concept of membrane reactors for chemical conversion has yet to be extensively commissioned for industrial application. However, some small industrial installations are active. The disadvantage of membrane reactors in order to be commercially industrialized are the membrane themselves, their support and issues including stability, cost and performance which require enhancement [8]. The combination of membranes and reactors is being proposed in recent years, and is classified into three i.e.; extractor, distributor and contactor. 'Extractor'this concept is used to selectively remove the product(s) from the reaction mixture. 'Distributor' is used to control the addition of reactants to the reaction mixture and lastly 'Contactor' is used to intensify the contact between reactants and the catalyst [8].
The forced flow-through contactor for VOC oxidation (which was also employed in this paper) is a distributor type concept mode which is largely employed by many researchers [13-21]. VOC destruction to carbon dioxide and water using $\mathrm{Pt} / \gamma$ $\mathrm{Al}_{2} \mathrm{O}_{3}$ catalysts has been claimed by several authors [22-26]. Additionally, Pt catalysts are superior in comparison to (gold) Au-containing systems and $\mathrm{Co}_{3} \mathrm{O}_{4}-\mathrm{CeO}_{2}$ mixed oxides [26, 27]. Pina et al., [28] have suggested the concept of employing the Knudsendiffusion catalytic membrane reactor for the combustion of VOCs. They have highlighted that a flowthrough configuration of a membrane reactor operating in the Knudsen diffusion regime provides an intimate contact between VOC and $\mathrm{O}_{2}$ molecules as well as the active sites. In another development, Saracco and Specchia, [29] have succeeded in using catalytic filters through tailored techniques. These catalytic filters were tested for their performance towards catalytic combustion of selected VOCs. Their experimental data corroborate with those predicted by an isothermal model based on a pseudo-homogeneous approach and solved numerically by the finite-difference method. In addition, Benard et al., [30] also studied the chemical reaction of the catalytic oxidation of VOCs for conventional and a flow-through catalytic membrane reactor comparison. Their findings exhibited that the catalytic membrane reactor was superior to the conventional one in terms of efficiency.

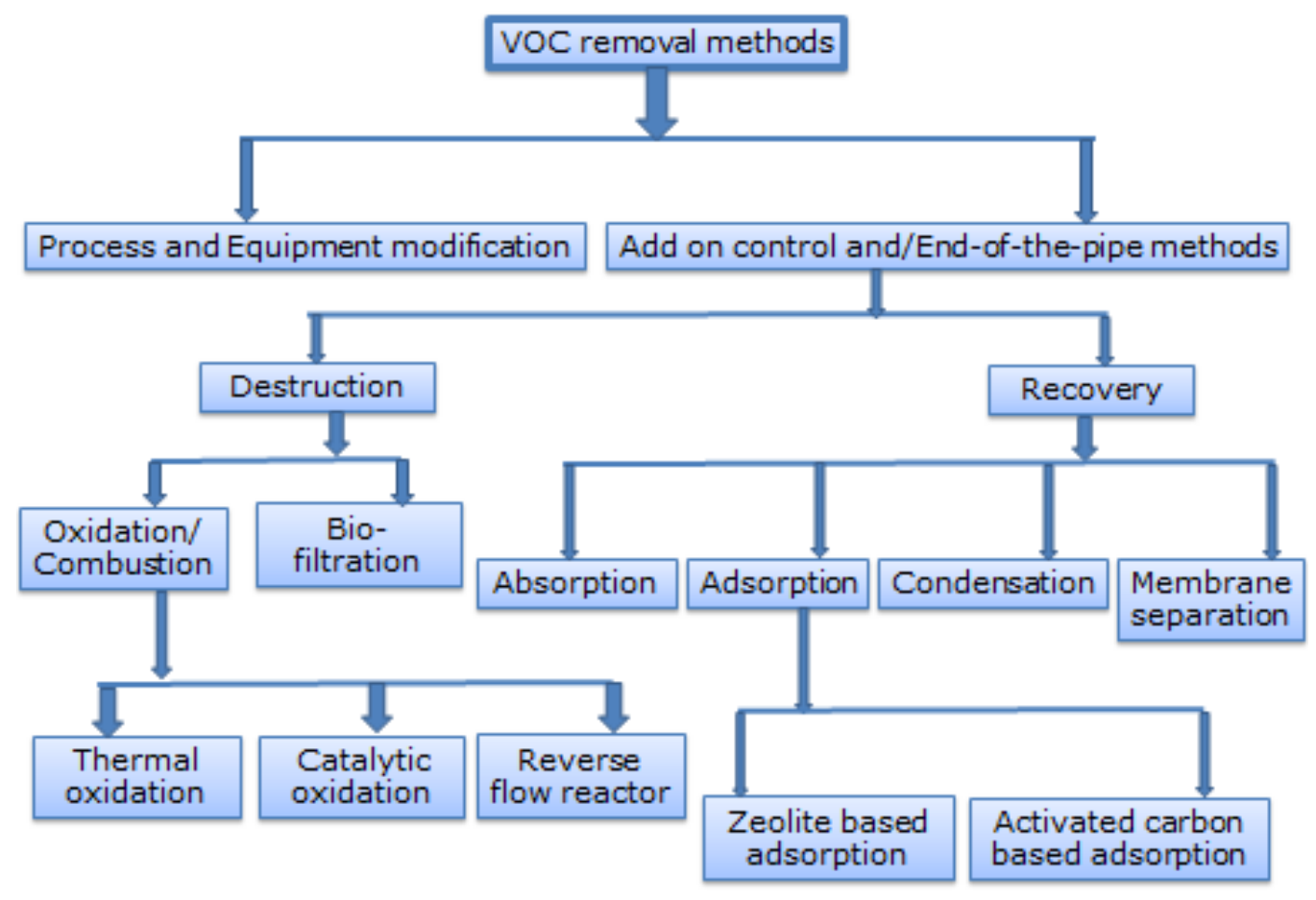

Figure 1: VOC controls methods [6]. 
They have suggested that, flow-through membrane reactor could lead to decreased light-off and total VOC combustion in addition to a lower Pt loading.

In this study, the performance of catalytic membrane reactor was studied with the aim to investigate the possibility of improving VOC conversion using a commercially available alumina $\left(\mathrm{Al}_{2} \mathrm{O}_{3}\right)$ support impregnated with $\mathrm{Pt}$ catalyst. The $\mathrm{Pt} / \gamma-\mathrm{Al}_{2} \mathrm{O}_{3}$ membrane was subsequently incorporated into a flowthrough membrane shell and tube configuration. The effects of the main operating variables such as the feed molar flow rates, reaction temperatures, and partial pressures were examined.

\section{EXPERIMENTATION}

A schematic diagram of the experimental rig is illustrated in Fig. 2. It consists of feed delivery (where pure gas was fed), a membrane reactor and analytical systems. The reactor used was tubular shell and tube configuration. The shell was made from stainless steel material and has $28 \mathrm{~mm}$ internal diameter (I.D), $36 \mathrm{~mm}$ outer diameter (O.D), 395mm long and $5 \mathrm{~mm}$ thick. The two ends of the reactor system were removable for membrane replacement purposes. Graphite rings (one at each end) were used as sealing for the alumina tube ends. The reactants were introduced into the reactor feed side using mass flow controllers. The reaction experiments occurred at atmospheric pressure within the stainless steel reactor. The product (permeate) was analysed by $\mathrm{CO}_{2}$ analyser (CT2100-Emissions Sensor). The water formed in the reaction was removed from the effluent in a moisture trap at room temperature.

Several factors were considered in selecting the membrane for this experiment. $\mathrm{Al}_{2} \mathrm{O}_{3}$ support was chosen because of its lower maintenance cost, although its permselectivity is slightly low. $\mathrm{Pt} / \gamma-\mathrm{Al}_{2} \mathrm{O}_{3}$ was used due to its high catalytic activity for VOC destruction [22, $27,31]$ leading to low operating temperature.

\subsection{Membrane Support}

The $\mathrm{Al}_{2} \mathrm{O}_{3}$ (symmetric membrane) tube supplied by Ceramiques Techniques et Industrielles (CTI SA) France, composed of $77 \% \mathrm{Al}_{2}$ and $23 \% \mathrm{TiO}_{2}$ possesses an I.D and O.D of 7 and $10 \mathrm{~mm}$ respectively. The $\mathrm{Al}_{2} \mathrm{O}_{3}$ consisted of a porous length of $348 \mathrm{~mm}$ and a porosity of 0.45 . This $\mathrm{Al}_{2} \mathrm{O}_{3}$ membrane was selected owing to the fact that it has good resistance to oxidation as well as chemical and mechanical stability at high temperature.

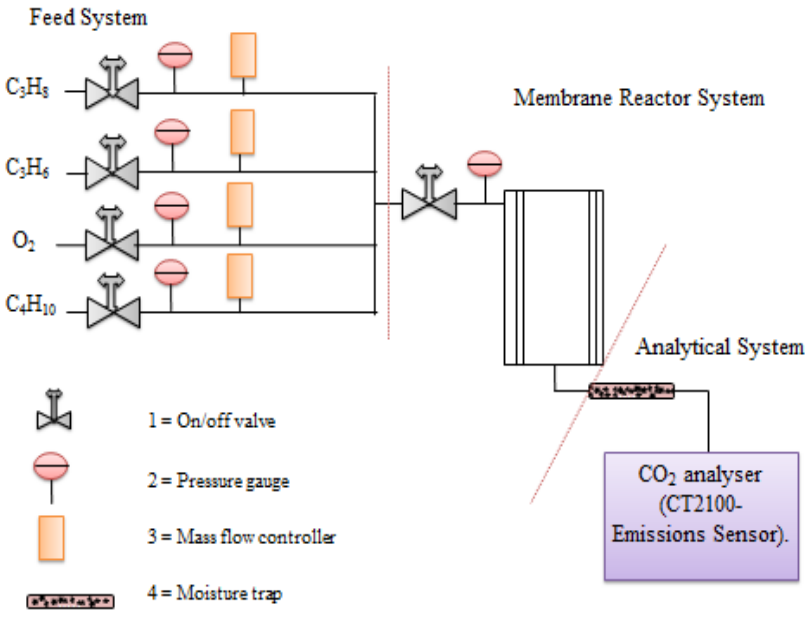

Figure 2: Schematic diagram of the feed, membrane reactor and analytical systems.

\subsection{Catalytic Membrane Preparation}

The $\mathrm{Pt} / \gamma-\mathrm{Al}_{2} \mathrm{O}_{3}$ membrane was prepared via dip-coating method. Chloroplatinic acid solution $\left(\mathrm{H}_{2} \mathrm{PtCl}_{6}\right)$ was used as a platinum precursor. The $\mathrm{Al}_{2} \mathrm{O}_{3}$ support was first dried at $65^{\circ} \mathrm{C}$. It was dipped for 2 hours in deionised water prior to $\mathrm{Pt}$ introduction.

The deposition method employed was based on the evaporation-crystallization steps. This system named as "reservoir" technique which was proposed by (Uzio, et al., 2003; Iojoiu et al., 2003; Kajama et al., 2016) [3236]. The $\mathrm{Al}_{2} \mathrm{O}_{3}$ tube was dipped in a $10 \mathrm{~g} / \mathrm{l} \mathrm{H}_{2} \mathrm{PtCl}_{6}$ precursor solution for 10 hours after it was dipped for 2 hours in deionised water. The $\mathrm{Pt} / \gamma-\mathrm{Al}_{2} \mathrm{O}_{3}$ membrane was then dried at room temperature for 24 hours to favour evaporation from the inner side and deposition on the top layer. Metallic platinum was obtained after thermal treatment of the $\mathrm{Pt} / \gamma-\mathrm{Al}_{2} \mathrm{O}_{3}$ membrane under flowing hydrogen at $400^{\circ} \mathrm{C}$ for at least $2 \mathrm{hrs}$ followed by nitrogen flow for $1 \mathrm{hr}$ at $400^{\circ} \mathrm{C}$ [35].

\subsection{Membrane Characterization}

SEM and EDXA of the membrane were examined before and after Pt impregnation. The samples used for SEM and EDXA were obtained by crushing the membrane into small pieces. SEM and EDXA results indicated the presence of Pt. The membrane was found to be defectfree.

\section{RESULTS AND DISCUSSION}

\subsection{Catalyst Characterization}

Platinum metal catalyst was employed due to its relatively high activity in VOC destruction over other noble metals [22]. BET surface area and the average pore size measurement of the $\mathrm{Al}_{2} \mathrm{O}_{3}$ support and $\mathrm{Pt} / \gamma$ - 
$\mathrm{Al}_{2} \mathrm{O}_{3}$ membrane samples were obtained. Table 1 presents the data of specific surface area, average pore diameter and pore volume of the $\mathrm{Al}_{2} \mathrm{O}_{3}$ support and $\mathrm{Pt} / \gamma-\mathrm{Al}_{2} \mathrm{O}_{3}$ membrane. The results clearly indicate an increase in BET surface area between the $\mathrm{Al}_{2} \mathrm{O}_{3}$ support and $\mathrm{Pt} / \gamma-\mathrm{Al}_{2} \mathrm{O}_{3}$ membrane. This increase may be attributed to the formation of nano-dispersed platinum particles. In addition, a decrease in the average pore diameter was obtained which is possibly due to pore blockage caused by the metal platinum particles. However, no alteration was observed with respect to the pore volume on both the $\mathrm{Al}_{2} \mathrm{O}_{3}$ support and $\mathrm{Pt} / \gamma^{-}$ $\mathrm{Al}_{2} \mathrm{O}_{3}$ membrane samples [36].

Table 1: BET surface area, average pore diameter and pore volume measurements of the Pt-alumina membrane [36].

\begin{tabular}{cccc}
\hline Catalyst & $\begin{array}{c}\text { BET } \\
\text { surface } \\
\text { area } \\
\left(\mathrm{m}^{2} / \mathrm{g}\right)\end{array}$ & $\begin{array}{c}\text { Average } \\
\text { pore } \\
\text { diameter } \\
(\mathrm{nm})\end{array}$ & $\begin{array}{c}\text { Pore } \\
\text { volume } \\
\left(\mathrm{cm}^{3} / \mathrm{g}\right)\end{array}$ \\
\hline Support & 0.364 & 4.171 & 0.005 \\
Pt-alumina & 0.426 & 3.7 & 0.005 \\
\hline
\end{tabular}

Nitrogen $\left(\mathrm{N}_{2}\right)$ adsorption/desorption isotherm of the calcined Pt dispersed membrane is shown (Figure 3a). The isotherm is a Type IV isotherm. Figure $3 \mathrm{~b}$ depicts the pore diameter measured by the Barrett-JoynerHalenda $(\mathrm{BJH})$ method of the calcined Pt membrane. The result reveals a fairly narrow pore size distribution. The average pore diameter was $3.7 \mathrm{~nm}$, and the majority of pore diameters are smaller than $50 \mathrm{~nm}$. In addition, the majority of pores are larger than can be successfully measured using gas sorption.

\subsection{SEM \& EDXA of Pt $/ \gamma-\mathrm{Al}_{2} \mathrm{O}_{3}$ Membrane}

SEM and EDXA of the $\mathrm{Pt} / \gamma-\mathrm{Al}_{2} \mathrm{O}_{3}$ membrane were examined after Pt impregnation. Figure 4 (a, b, c and d) depict the SEM images of the Pt membranes inner, outer, cross-section and edge respectively. $\mathrm{Pt}$ depositions can be clearly observed on the SEM images shown on Figures 4 ( $a$ and $b$ ). The SEM image of the edge of the $\mathrm{Pt} / \gamma-\mathrm{Al}_{2} \mathrm{O}_{3}$ membrane is also shown on Figure 4 (d) with a thickness of between 10-12 microns.

Moreover, the compositional results are shown (Table 2). After Pt impregnation, it can be seen (Table 2) that a $3.52 \mathrm{wt} \% \mathrm{Pt}$ is obtained. Pt is the active catalyst for the proposed reaction in order to facilitate the reaction of $\mathrm{VOC}$ and $\mathrm{O}_{2}$ to generate $\mathrm{CO}_{2}$ and $\mathrm{H}_{2} \mathrm{O}$.

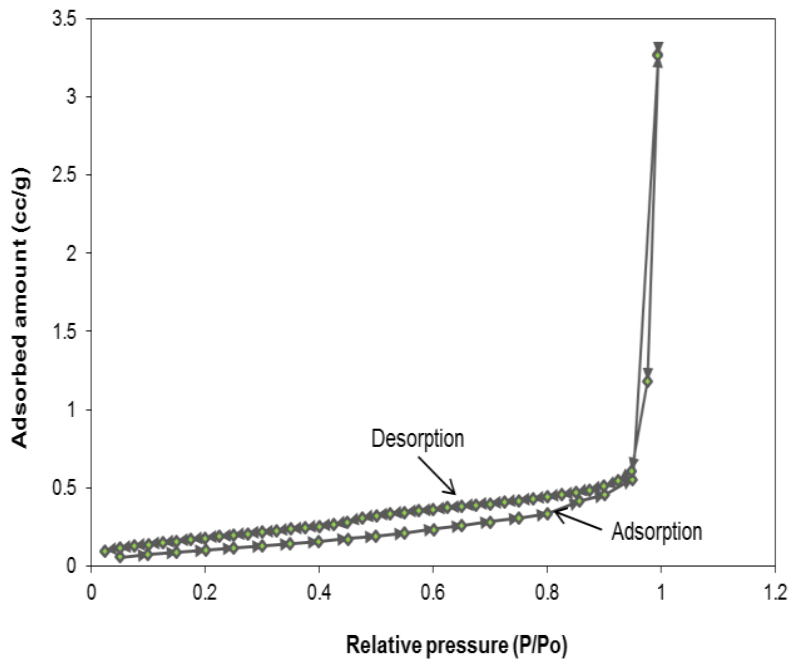

(a)

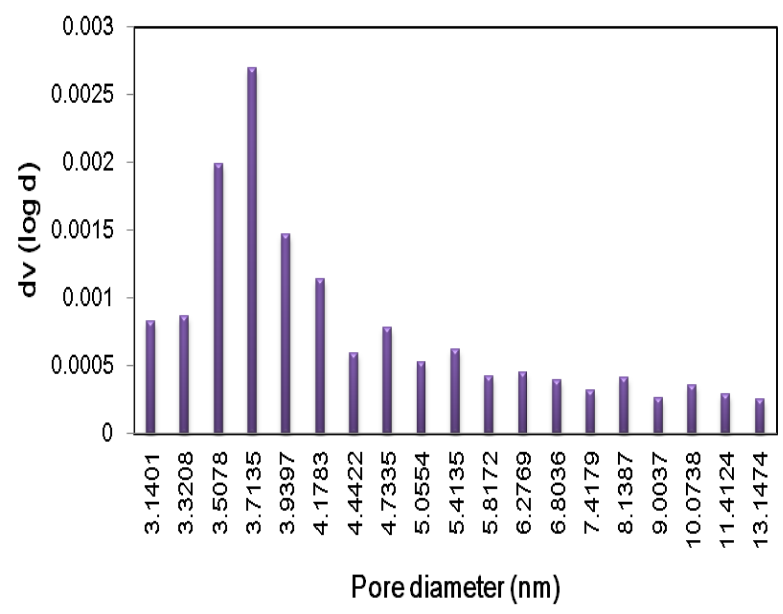

(b)

Figure 3: (a) $N_{2}$ adsorption/desorption isotherm of Pt membrane (b) Pore-size distribution of Pt membrane measured by $N_{2}$ adsorption.

Table 2: Outer surface EDXA of Pt membrane [37].

\begin{tabular}{lll}
\hline Element & Weight (\%) & Atomic (\%) \\
\hline $\mathrm{CaCO}_{3}(\mathrm{C} \mathrm{K})$ & 14.41 & 19.64 \\
$\mathrm{SiO}_{2}(\mathrm{O} \mathrm{K})$ & 50.68 & 51.88 \\
$\mathrm{Al}_{2} \mathrm{O}_{3}(\mathrm{Al} \mathrm{K})$ & 38.52 & 23.38 \\
$\mathrm{SiO}_{2}(\mathrm{Si} \mathrm{K})$ & 0.28 & 0.16 \\
$\mathrm{KCl}(\mathrm{Cl})$ & 3.28 & 1.51 \\
Wollastonite (Ca K) & 0.32 & 0.13 \\
Titanium (Ti K) & 7.94 & 2.72 \\
Zirconium (Zr L) & 1.61 & 0.29 \\
Platinum (Pt M) & 3.52 & 0.30 \\
Total & 120.56 & 100.02 \\
\hline
\end{tabular}



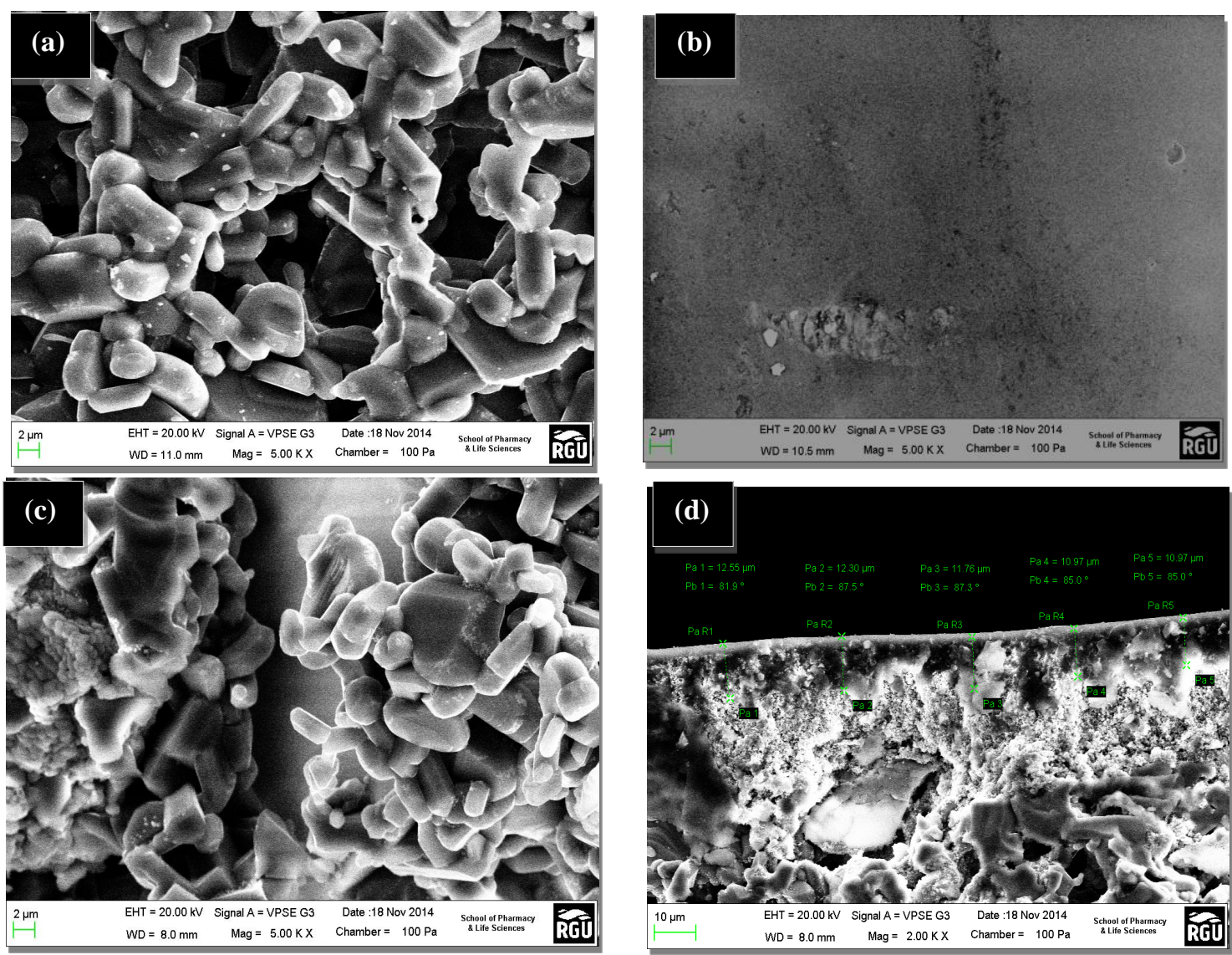

Figure 4: (a) SEM image of the Pt membrane inner surface (b) SEM image of the Pt membrane outer surface (c) SEM image of the Pt membrane cross-sectional area (d) SEM image of the Pt membrane edge surface.

\subsection{Gas Permeation}

Permeation experiments were carried out at room temperature using propylene single gas in order to quantify Knudsen flow contribution. Figure 5 depicts the permeate flux of the virgin and $\mathrm{Pt} / \mathrm{Al}_{2} \mathrm{O}_{3}$ membranes. Eqn. (2) was used to relate the permeation flux and average pressure [28].

$$
F=\beta P_{a v}+K
$$

where $\beta$ and $K$ are given by;

$$
\beta=0.125 \frac{\varepsilon r^{2}}{L \tau \mu R T}, K=1.06 \frac{\varepsilon r}{L \tau \sqrt{M R T}}
$$

where, $F$ is the permeation flux per unit of time and area, $\varepsilon$ is the porosity of the membrane (\%), $r$ is the mean pore radius $(\mathrm{m}), P_{a v}=\left(\mathrm{P}_{1}+\mathrm{P}_{2}\right) / 2$ is the average pressure (Pa), $\mu$ is the viscosity (Pa-s) and $L$ is the thickness of the membrane (m), $\tau$ is the tortuosity, $M$ is the molecular weight of the diffusing gas $(\mathrm{g} / \mathrm{mol}), R$ gas constant (8.314 J.K $\left.\mathrm{K}^{-1} \cdot \mathrm{mol}^{-1}\right)$ and $T$ the permeation temperature (K). $\beta$ and $K$ can be regarded as viscous and Knudsen contributions to the permeation flux [28]. It can be seen (Figure 5) that the $\mathrm{Al}_{2} \mathrm{O}_{3}$ (virgin membrane) was influenced mainly by viscous flow contribution. On the other hand, after $3.52 \mathrm{wt} \% \mathrm{Pt}$ impregnation, a lower slope was obtained for the $\mathrm{Pt} / \gamma$ -
$\mathrm{Al}_{2} \mathrm{O}_{3}$ membrane with a decrease of permeates flux (Figure 5) from (8.8 to $8.2 \times 10^{-6}$ ) which indicates Knudsen diffusion contribution. The obtained result is in agreement with the literature [28]. Pina, et al., [28] obtained similar results using untreated gammaalumina $\left(\alpha-\mathrm{Al}_{2} \mathrm{O}_{3}\right)$ membrane. After depositing $4.9 \mathrm{wt} \%$ of $\gamma-\mathrm{Al}_{2} \mathrm{O}_{3}$ at 1 bar, they achieved an almost horizontal line indicating predominantly Knudsen diffusion contribution.

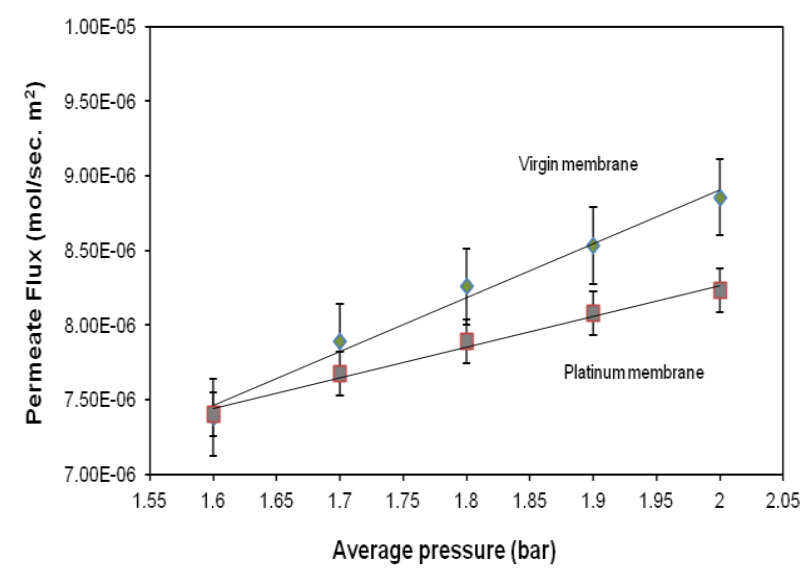

Figure 5: Permeation flux across alumina support (virgin membrane) and platinum membrane against average pressure at room temperature. 


\subsection{VOC Conversion}

A $\mathrm{CO}_{2}$ analyser (Cascade's CT2100 sensors) was connected from the catalytic membrane reactor permeate side. As the reactants (VOC and $\mathrm{O}_{2}$ ) were fed into the feed side of the catalytic membrane reactor, combustion/conversion occurred at different flow rates, pressures and reaction temperatures, where the products $\left(\mathrm{CO}_{2}\right.$ and $\left.\mathrm{H}_{2} \mathrm{O}\right)$ permeated through the permeate side of the membrane reactor, passing through the moisture trap (where the $\mathrm{H}_{2} \mathrm{O}$ is been absorbed) through a digital flowmeter to the $\mathrm{CO}_{2}$ analyser in order to record the percentage concentration of the product $\mathrm{CO}_{2}$. The $\mathrm{CO}_{2}$ analyser was calibrated before the experiment. The conversion of VOCs was calculated using eqn. (4) [38, 39].

$$
X_{V O C}(\%)=\frac{V O C_{i}-V O C_{o}}{V O C_{i}} \times 100
$$

where $V O C_{i}$ is the flow rate of $\mathrm{VOC}$ at the feed recorded from the flow meter, and $V O C_{o}$ is the permeate flow rate of VOC at the permeate recorded from the flow meter respectively. The catalytic membrane was exposed to several activity runs. The same membrane was then cooled down prior to each experiment.

Figure 6 depicts propane conversion against reaction temperature across $3.52 \mathrm{wt} \% \mathrm{Pt}-\mathrm{Al}_{2} \mathrm{O}_{3}$ membrane at flow rates between 185 to $222 \mathrm{ml} / \mathrm{min}$ without any changes in conversion. The general behaviour of the $\mathrm{Pt} / \gamma-\mathrm{Al}_{2} \mathrm{O}_{3}$ based catalysts result is in good agreement with that reported in the literature. Propane conversion of $93 \%$ was achieved at a temperature of $427^{\circ} \mathrm{C}$, this result corroborates the literature [29]. This could be as a result of strong interaction of the $\mathrm{Pt}$ catalyst which facilitated the chemical reaction at lower temperature compared to thermal oxidation. It should be noted that this conversion was attained at only a fraction of the catalyst loading compared to the literature [29].

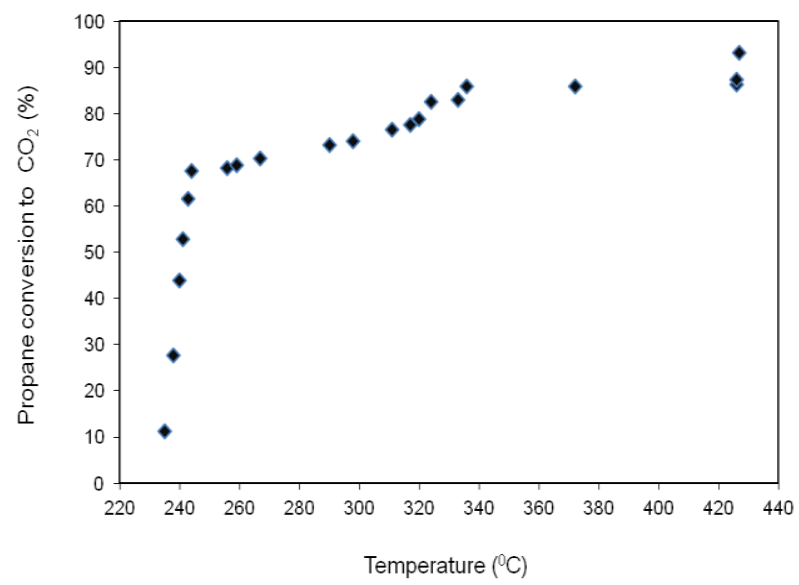

Figure 6: Propane conversion against reaction temperature.
Figure 7 depicts the conversion of $n$-butane against reaction temperature across $3.52 \mathrm{wt} \% \quad \mathrm{Pt}_{-} \mathrm{Al}_{2} \mathrm{O}_{3}$ membrane at flow rates between 295 to $379 \mathrm{ml} / \mathrm{min}$ without any changes in conversion. It can be seen (Figure 7) that the highest n-butane conversion of $48 \%$ was achieved at a temperature of $259^{\circ} \mathrm{C}$ on $\mathrm{Pt} / \gamma-\mathrm{Al}_{2} \mathrm{O}_{3}$ membrane. This demonstrates that the performance of a catalytic membrane reactor is influenced by the operating parameter such as temperature.

In order to compare the conversions between the aliphatic hydrocarbons (propane and n-butane), a $48 \%$ propane conversion was achieved at only $242^{\circ} \mathrm{C}$ whereas in the case of $n$-butane a $48 \%$ was achieved at a temperature of $259^{\circ} \mathrm{C}$. In other words, propane recorded lower reaction temperature than n-butane at $48 \%$. The high activity behaviour could be possibly due to the ability of Pt catalyst over propane compared to n-butane.

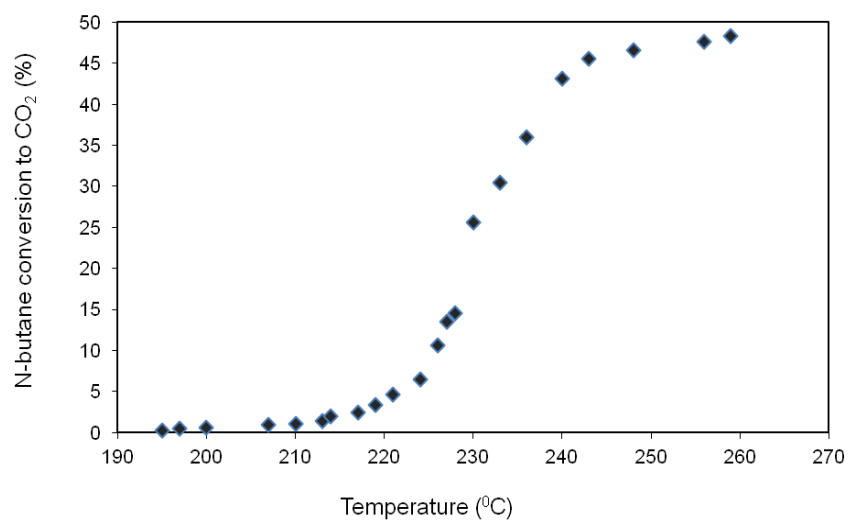

Figure 7. N-butane conversion against reaction temperature.

The above result is an indicative where the temperature at which the combustion takes place depends on the nature of the VOC present in the waste gas stream as well as the $\mathrm{Pt} / \gamma-\mathrm{Al}_{2} \mathrm{O}_{3}$ membrane.

\section{CONCLUSIONS}

The experimental VOC conversion using a flow-through catalytic membrane reactor operating in the Knudsen diffusion regime has been demonstrated using the simple but effective "reservoir technique". The stainless steel membrane reactor designed was operated at hightemperature without any deterioration. VOC conversion was significantly higher. The conversion of VOC using $\mathrm{Pt} / \gamma-\mathrm{Al}_{2} \mathrm{O}_{3}$ membrane was obtained at moderate temperatures. Consequently, the maximum conversion obtained by the $\mathrm{Pt}-\mathrm{Al}_{2} \mathrm{O}_{3}$ membrane was comparable with literature. The membrane employed maintained a prolong activity and stability without any catalytic degradation. 


\section{ACKNOWLEDGEMENTS}

The authors gratefully acknowledge Petroleum Technology Development Fund (PTDF) Nigeria for funding this research; Centre for Process Integration and Membrane Technology, (CPIMT) School of Engineering, The Robert Gordon University, Aberdeen, United Kingdom for providing the membrane reactor, and School of Pharmacy \& Life Sciences RGU Aberdeen for the SEM results.

\section{REFERENCES}

[1] Aguado S, Coronas J, Santamaría J. Use of zeolite membrane reactors for the combustion of VOCs present in air at low concentrations. Chemical Engineering Research and Design; 83 (3):295301, 2005.

[2] Pina M, Irusta S, Menéndez M, Santamaria J, Hughes R, Boag N. Combustion of volatile organic compounds over platinum-based catalytic membranes. Ind Eng Chem Res; 36 (11):4557-4566 1997.

[3] Atkinson, R. Atmospheric chemistry of VOCs and NOx. Atmospheric Environment, (34):2063-2101, 2000.

[4] Rusu A. O., Dumitriu E. Destruction of volatile organic compounds by catalytic oxidation. Environmental Engineering and Management Journal; 2(4):273-302, 2003.

[5] Liotta L. F. Catalytic oxidation of volatile organic compounds on supported noble metals. Applied Catalysis B: Environmental;100 (34):403-412, 2010.

[6] Khan FI, Ghoshal AK. Removal of volatile organic compounds from polluted air. J Loss Prev Process Ind; 13 (6):527-545, 2000.

[7 Tamaddoni M, Sotudeh-Gharebagh R, Nario S, Hajihosseinzadeh M, Mostoufi N. Experimental study of the VOC emitted from crude oil tankers. Process Saf Environ Prot; 92 (6):929937, 2014.

[8] Julbe A, Farrusseng D, Guizard C. Porous ceramic membranes for catalytic reactorsoverview and new ideas. J Membr Sci; 181 (1):3-20, 2001.

[9] Coronas J, Santamaria J. Catalytic reactors based on porous ceramic membranes. Catalysis Today, 51 (3):377-389, 1999.

[10] Hwang S. Inorganic membranes and membrane reactors. Korean Journal of Chemical Engineering, 18 (6):775-787, 2001.

[11] Lu G, da Costa J. D., Duke M, Giessler S, Socolow $\mathrm{R}$, Williams $\mathrm{R}$, et al. Inorganic membranes for hydrogen production and purification: a critical review and perspective. J Colloid Interface $S c i$; 314 (2):589-603, 2007.

[12] Uemiya S. Brief review of steam reforming using a metal membrane reactor. Topics in Catalysis; 29 (1-2):79-84, 2004.

[13] Saracco G, Specchia V. Catalytic ceramic filters for flue gas cleaning. 2. Catalytic performance and modeling thereof. Ind Eng Chem Res; 34 (4):1480-1487, 1995.

[14] Irusta S, Pina M, Menendez M, Santamaria J. Development and application of perovskitebased catalytic membrane reactors. Catalysis letters; 54 (1-2):69-78 1998.

[15] Dittmeyer R, Höllein V, Daub K. Membrane reactors for hydrogenation and dehydrogenation processes based on supported palladium. Journal of Molecular Catalysis A: Chemical;; 173(1):135-184, 2001.

[16] Lange C, Storck S, Tesche B, Maier W. Selective hydrogenation reactions with a microporous membrane catalyst, prepared by sol-gel dip coating. Journal of Catalysis; 175 (2):280-293, 1998.

[17] Yamada M, Fugii K, Haru H, Itabashi K. Preparation and catalytic properties of special alumina membrane formed by anodic oxidation of aluminum. The Light Metal Educational Foundation, Inc., Report of the Research Group for Functionalizing of Aluminum and Its Surface Films: 175-182, 1988.

[18] Splinter A, Stürmann J, Bartels O, Benecke W. Micro membrane reactor: a flow-through membrane for gas pre-combustion. Sensors Actuators B: Chem,; 83(1):169-174 2002.

[19] Zalamea S, Pina M, Villellas A, Menéndez M, Santamaría J. Combustion of volatile organic compounds over mixed-regime catalytic membranes. Reaction Kinetics and Catalysis Letters, 67 (1):13-19, 1999.

[20] Maira A. J, Lau WN, Lee C. Y, Yue PL, Chan C. K, Yeung K. L. Performance of a membranecatalyst for photocatalytic oxidation of volatile organic compounds. Chemical engineering science,;58(3):959-962 2003.

[21] Tsuru T, Kan-no T, Yoshioka T, Asaeda M. A photocatalytic membrane reactor for gas-phase reactions using porous titanium oxide membranes. Catalysis Today, 82 (1):41-48, 2003.

[22] Benard S, Ousmane M, Retailleau L, Boreave A, Vernoux P, Giroir-Fendler A. Catalytic removal of propene and toluene in air over noble metal catalyst. Canadian Journal of Civil Engineering, 36(12):1935-1945, 2009. 
[23] Radic N, Grbic B, Terlecki-Baricevic A. Kinetics of deep oxidation of n-hexane and toluene over $\mathrm{Pt} / \mathrm{Al}_{2} \mathrm{O}_{3}$ catalysts: Platinum crystallite size effect. Applied Catalysis B: Environmental,; 50 (3):153-159 2004.

[24] Kim D. H, Kung M. C, Kozlova A, Yuan S, Kung H. $\mathrm{H}$. Synergism between $\mathrm{Pt} / \mathrm{Al}_{2} \mathrm{O}_{3}$ and $\mathrm{Au} / \mathrm{TiO}_{2}$ in the low temperature oxidation of propene. Catalysis letters; 98 (1):11-15, 2004.

[25] Tahir SF, Koh C. A. Catalytic destruction of volatile organic compound emissions by platinum based catalyst. Chemosphere; 38 (9): 2109-2116, 1999.

[26] Gluhoi A. C, Bogdanchikova N, Nieuwenhuys BE. Total oxidation of propene and propane over gold-copper oxide on alumina catalysts: Comparison with $\mathrm{Pt} / \mathrm{Al}_{2} \mathrm{O}_{3}$. Catalysis today, 113 (3):178-181, 2006.

[27] Liotta L, Ousmane M, Di Carlo G, Pantaleo G, Deganello G, Boreave A, et al. Catalytic removal of toluene over $\mathrm{Co}_{3} \mathrm{O}_{4}-\mathrm{CeO}_{2}$ mixed oxide catalysts: comparison with $\mathrm{Pt} / \mathrm{Al}_{2} \mathrm{O}_{3}$. Catalysis Letters; 127(3-4):270-276, 2009.

[28] Pina M, Menéndez M, Santamaria J. The Knudsen-diffusion catalytic membrane reactor: an efficient contactor for the combustion of volatile organic compounds. Applied Catalysis B: Environmental; 11 (1):L19-L27, 1996.

[29] Saracco G, Specchia V. Catalytic filters for the abatement of volatile organic compounds. Chemical Engineering Science; 55(5):897-908, 2000.

[30] Bénard S, Giroir-Fendler A, Vernoux P, Guilhaume N, Fiaty K. Comparing monolithic and membrane reactors in catalytic oxidation of propene and toluene in excess of oxygen. Catalysis Today, 156(3):301-305, 2010.

[31] Paulis M, Peyrard H, Montes M. Influence of chlorine on the activity and stability of $\mathrm{Pt} / \mathrm{Al}_{2} \mathrm{O}_{3}$ catalysts in the complete oxidation of toluene. Journal of Catalysis; 199 (1):30-40, 2001.

[32] Uzio D, Miachon S, Dalmon J. Controlled Pt deposition in membrane mesoporous top layers. Catalysis today, 82 (1):67-74, 2003.

[33] Iojoiu E, Walmsley J, Raeder H, Bredesen R, Miachon S, Dalmon J. Comparison of different support types for the preparation of nanostructured catalytic membranes. Reviews on Advanced Materials Science; 5(3):160-165, 2003.

[34] Kajama M. N., Nwogu N. C, Gobina E. Preparation and characterization of inorganic membranes for hydrogen separation. International Journal of Hydrogen Energy; 41 (19):8221-8227, 2016.

[35] Kajama M. N, Nwogu N. C., Gobina E. Catalytic membrane reactor for VOC destruction 1. Transactions on Engineering Technologies; 163177, 2016.

[36] Kajama M. N., Shehu H, Okon E, Orakwe I, Gobina E. VOC oxidation in excess of oxygen using flowthrough catalytic membrane reactor. International Journal of Hydrogen Energy; 41(37):1652916534, 2016.

[37] Kajama M. N, Nwogu N. C, Okon E. O, Shehu H, Orakwe I, Gobina E. Hydrogen Separation Using Pt-Alumina Impregnated Membrane. Energy and Power Engineering; 7:412-417,2015.

[38] Delimaris D, Ioannides T. VOC oxidation over $\mathrm{MnOx}-\mathrm{CeO}_{2}$ catalysts prepared by a combustion method. Applied Catalysis B: Environmental; 84(1):303-312, 2008.

[39] Delagrange S, Pinard L, Tatibouet J. M. Combination of a non-thermal plasma and a catalyst for toluene removal from air: Manganese based oxide catalysts. Applied Catalysis B: Environmental; 68(3):92-98, 2006. 